\title{
Environmental Toxicity Assessment: state of the art and future directions in a world of arising threats
}

\author{
Christina Emmanouil $^{1} \cdot$ Athanasios Kungolos $^{2}$ \\ Published online: 4 January 2021 \\ (C) The Author(s), under exclusive licence to Springer-Verlag GmbH, DE part of Springer Nature 2021
}

The present editorial introduces to a Special Issue in Environmental Science and Pollution Research journal, highlighting selected papers presented at the 19th International Symposium on Toxicity Assessment (ISTA19) that was held in Thessaloniki, Greece, in August 2019. For more than 30 years, the biennial ISTA congresses serve as a catalyst for fruitful exchanges between researchers, managers, and legislators involved in all fields of environmental science, safety, and health. ISTA provides a forum for discussions on current advances in toxicity and risk assessment, on fundamental or innovative concepts in ecotoxicology, as well as on research on environmental protection and conservation. Nowadays, investigation of environmental toxicity is more necessary than ever; the general public is continuously bombarded with various environmental agents - some of them less than innocuous, permissible exposure limits for workers are commonly revaluated and new scientific data enable us to ban, limit, restrict, or re-register pesticides and other chemicals. At the same time, novel testing technologies and tools continue to emerge. These techniques utilize fewer live organisms and they are in vitro and in silico oriented. Thus, there is a need for developing a long-range vision and strategy for toxicity testing that encompasses more humane methods without compromising validity and reliability. Only this approach will be able to give answers to current and imminent environmental problems.

Responsible editor: Philippe Garrigues

Christina Emmanouil

chemmanouil@plandevel.auth.gr

Athanasios Kungolos

kungolos@ civil.auth.gr

1 School of Spatial Planning and Development, Aristotle University of Thessaloniki, Thessaloniki, Greece

2 School of Civil Engineering, Aristotle University of Thessaloniki, Thessaloniki, Greece
The following 12 manuscripts are just a glimpse of these concerns that were talked about in ISTA19. At the same time, these selected manuscripts demonstrate the breadth of toxicity assessments being conducted globally.

It would be a great disservice to ISTA's ideology if we forgot where we originated from; as such, the special issue opens with the participation of Professor Paule Vasseur and her team (Vasseur et al. 2020) on how it all started with "Ecotoxicology, revisiting its pioneers."

Right after diving into the past, we emerge in the present with the presentation of an ultrarapid screening test developed by Snell and Persoone (2020). The test uses a desiccated rotifer which, when rehydrated, can easily classify water-based samples into four toxic categories.

From novel bioassays to well-established ones, we continue with the research of Courtois et al. (2020) on how the model organism Eisenia foetida accumulates and biotransforms $\mathrm{Ag}$, which is increasingly used in agriculture, especially in nanoparticle form.

Staying in the crop field, we then investigated the $h r p Z_{P s p h^{-}}$ transgenic Nicotiana benthamiana response under Cd stress (Mitsopoulou et al. 2020) and how it differs from its wild-type homologue.

The realistic threat of $\mathrm{Cd}$ soil contamination as well as $\mathrm{Cr}$ contamination was the focus of research of Antoniadis and Golia (2020) on agricultural soils in Central Greece. It was shown that the pollution arises from fertilizers, but it also has a lithogenic component.

Contamination of soil by toxic metals was also the research focus of the review of Charvalas et al. (2021). Case studies of Chalikidiki and Kozani in Greece were chosen in order to showcase the potential of phytoremediation, in relation to the local flora characteristics.

Intensive agriculture and clashing land uses further facilitate soil metal contamination in Greece; as such, our own research here (Giannakis et al. 2020) examined how land 
spreading of municipal sludge may affect this burden in the long run, at soils which have received this treated waste twice in the course of 2 years.

Moving on from land to water, newly synthesized rubberbased sorbents were tested as passive samplers for polycyclic aromatic hydrocarbons (Tureyen et al. 2020). It was shown that at least the sampler prepared in benzene performed very well and it could be used for both short- and long-term monitoring in the aquatic environment.

Passive samples were also subject of the research from Sofield et al. (2021); in their paper, the authors investigated how water quality parameters affect metal accumulation kinetics in freshwater so that these modifying factors are also considered.

Besides chemical pollution, aquatic ecosystems may also suffer from toxic blooms. The vulnerable Mediterranean basin has been chosen as a case study for the review of Marampouti et al. (2020), who have also considered the origin and the impact of 20 contributing invasive species.

Regarding aquatic pollution and wastewater treatment, the research group of Médice et al. (2020) has focused on norfloxacin, a common antibiotic, which after wastewater chlorination produces various by-products of documented ecotoxicity.

On the same plane, another durable pollutant, the fungicide fludioxonil, was treated on upflow immobilized cell bioreactor so that it could be successfully metabolized, in the study of Mavriou et al. (2020).

As already stated, these manuscripts mirror the broad and multidisciplinary research presented and promoted in ISTA19. This joint effort was fruitful because of the dedication and the punctuality of the authors, the professionalism and the commitment of the ESPR journal, and the perseverance and the enthusiasm of the ISTA organizing team. We are looking forward to the next ISTA congresses, to an expanding international audience, and to the continuous participation of scientists, assessors, policy makers, and sensitized public.

\section{References}

Antoniadis V, Golia EE (2020) Spatial and temporal assessment of cadmium and chromium contamination in soils in the Karditsa region (Central Greece). Environ Sci Pollut Res. https://doi.org/10.1007/ s11356-020-09273-3

Charvalas G, Solomou AD, Giannoulis KD, Skoufogianni E, Bartzialis D, Emmanouil C, Danalatos1 NG (2021) Determination of heavy metals in the territory of contaminated areas of Greece and their restoration through hyperaccumulators. Environ Sci Pollut Res. https://doi.org/10.1007/s11356-020-11920-8

Courtois P, Rorat A, Lemiere S, Levard C, Chaurand P, Grobelak A, Lors C, Vandenbulcke F (2020) Accumulation, speciation and localization of silver nanoparticles in the earthworm Eisenia fetida. Environ Sci Pollut Res. https://doi.org/10.1007/s11356-020-08548-z

Giannakis I, Emmanouil C, Mitrakas M, Manakou V, Kungolos A (2020) Chemical and ecotoxicological assessment of sludge-based biosolids used for corn field fertilization. Environ Sci Pollut Res. https://doi.org/10.1007/s11356-020-09165-6
Marampouti C, Buma AGJ, de Boer MK (2020) Mediterranean alien harmful algal blooms: origins and impacts. Environ Sci Pollut Res. https://doi.org/10.1007/s11356-020-10383-1

Mavriou Z, Alexandropoulou I, Melidis P, Karpouzas DG, Ntougias S (2020) Biotreatment and bacterial succession in an upflow immobilized cell bioreactor fed with fludioxonil wastewater. Environ Sci Pollut Res. https://doi.org/10.1007/s11356-02009231-z

Médice RV, de Cássia Franco Afonso RJ, Almeida MLB, de Aquino SF, Libânio M (2020) Preliminary assessment of antimicrobial activity and acute toxicity of norfloxacin chlorination by-product mixture. Environ Sci Pollut Res. https://doi.org/10.1007/s11356-020-097483

Mitsopoulou N, Lakiotis K, Golia EE, Khah EM, Pavli OI (2020) Response of hrpZPsph-transgenic N. benthamiana plants under cadmium stress. Environ Sci Pollut Res. https://doi.org/10.1007/ s11356-020-09204-2

Snell TW, Persoone G (2020) A rapid, simple screening toxicity test using desiccated bdelloid rotifers: Rotifer Activity Inhibition Test (RAIT). Environ Sci Pollut Res. https://doi.org/10.1007/s11356020-09255-5

Sofield RM, Brown EA, Bonnard J, Eberle CN, Jensen WJ, Johnson AM, Miller JD, Yamaura AJ (2021) Influence of various water quality parameters on passive sampler accumulation kinetics of different metal valencies in freshwater. Environ Sci Pollut Res. https://doi. org/10.1007/s11356-020-11570-w

Tureyen OE, Yilmaz A, Yakan SD, Yetiskin B, Okay O, Okay OS (2020)Performance of butyl rubber-based macroporous sorbents as passive samplers. Environ Sci Pollut Res. https://doi.org/10. 1007/s11356-020-08945-4

Vasseur P, Masfaraud J-F, Blaise C (2020) Ecotoxicology, revisiting its pioneers. Environ Sci Pollut Res. https://doi.org/10.1007/s11356020-11236-7

Publisher's note Springer Nature remains neutral with regard to jurisdictional claims in published maps and institutional affiliations.

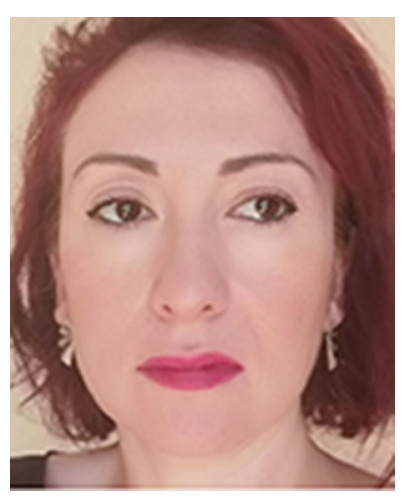

Dr Christina Emmanouil works as lecturer in Department of Spatial Planning and Development in Aristotle University of Thessaloniki (AUTH) and as a visiting lecturer in University of West Macedonia. She has received her bachelor's degree from National Hellenic University of Athens and her post-graduate degrees in Environmental Sciences from the University of Birmingham, UK. Her previous tasks included being an environmental risk assessor for Plant Protection Products and their substances according to Dir.91/414/EEC and Reg.1107/2009/EC and for biocides according to Dir.98/8/EC for Greek Ministry of Agriculture (Benaki Phytopathological Institute, BPI), a lecturer and a research associate in various environmental-related projects. Her current work involves pollution monitoring and effects on humans and the ecosystem. She has published 25 papers in peer-reviewed journals, co-authored 2 books and 4 book chapters and she has taken part as an investigator or principal investigator in more than 25 projects in AUTH, BPI, University of Thessaly and Agricultural University of Athens. 


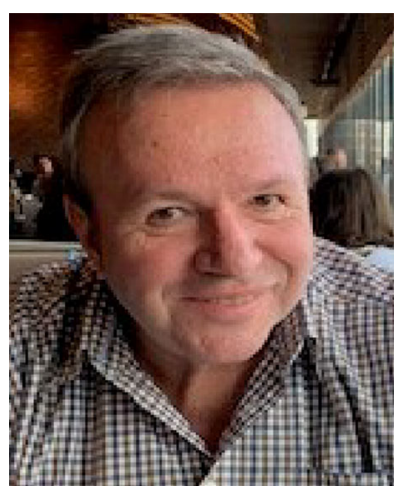

Dr Athanasios Kungolos is Professor in Environmental Management and Engineering in the Department of Civil Engineering of Aristotle University of Thessaloniki (AUTH), Greece. Before that, he was a Professor under the same discipline in Department of Planning and Regional Development of the University of Thessaly, Greece. He has graduated from the Department of Chemical Engineering of AUTH and his postgraduate studies (M.Sc. and $\mathrm{Ph} . \mathrm{D}$.) were awarded from the University of Okayama in Japan. During his 25 year-spanning academic career, Prof. Kungolos has taught at undergraduate and postgraduate level on various thematic fields including Environmental planning, Environmental management, Water quality, Waste management and Environmental toxicology. He has acted a chief-coordinator in more than 50 R\&D programmes financed by European, national or private-sector funds, with focus on environmental management and risk assessment. He has published 80 papers in peer-reviewed journals, (co)-written 5 educational books and 6 book-chapters and issued more than 15 proceedings of international peer-reviewed conferences. Past and present managerial positions include: vice-president of Department of Civil Engineering, AUTH (2020), member of the managerial board (2018) of International Hellenic University, acting member (20162019) of DOATAP (Hellenic National Academic Recognition Information Center) Administrative Council, vice rector of Research and Development (2013-2014), of the University of Thessaly and chairperson of Society of Ecotoxicology and Environmental Safety (SECOTOX) (2007-2020). 